\title{
IDENTIFICATION OF THE CONTENT OF BIOLOGICALLY ACTIVE SUBSTANCES IN NUT MEALS
}

\author{
Elena Shydakova-Kameniuka \\ Department of Bakery, Confectionary, Pasta and Food Concentrates Technology \\ Kharkiv State University of Food Technology and Trade \\ 333 Klochkivska str., Kharkiv, Ukraine, 61051 \\ shidakovae@gmail.com \\ Anna Novik \\ Department of Food Technologies \\ Oles Honchar Dnipro National University \\ 72 Gagarina ave., Dnipro, Ukraine, 49010 \\ anna.novik.82@ukr.net \\ Yevhenii Zhukov \\ Department of Tourism and Hotel Business \\ Kharkiv Institute of Trade and Economics \\ Kyiv National University of Trade and Economics \\ 8 O. Yarosha str., Kharkiv, Ukraine, 61045 \\ qsm@yandex.com \\ Yuliia Matsuk \\ Department of Food Technologies \\ Oles Honchar Dnipro National University \\ 72 Gagarina ave., Dnipro, Ukraine, 49010 \\ lyly2006@ukr.net \\ Anna Zaparenko \\ Department of Food Technologies and Restaurant Business \\ Kharkiv Institute of Trade and Economics \\ Kyiv National University of Trade and Economics \\ 8 O. Yarosha str., Kharkiv, Ukraine, 61045 \\ kindeducation@gmail.com \\ Philipp Babich \\ Department of hotel and Restaurant Business \\ Dniprovskiy University of Humanities, \\ 1-b Orlovskaya str., Dnipro, Ukraine, 49064 \\ 380637962008f@gmail.com

\section{Svitlana Oliinyk} \\ Department of Bakery, Confectionary, Pasta and Food Concentrates Technology \\ Kharkiv State University of Food Technology and Trade \\ 333 Klochkivska str., Kharkiv, Ukraine, 61051 \\ svitlana.oliinyk@gmail.com
}

\footnotetext{
Abstract

One of ways of the food industry development is a search for non-traditional raw material resources with the high content of physiologically healthy nutrients. A promising way of biologically important raw materials is secondary products of oil production, especially meals. The aim of the research was to determine the content of biologically active substances in nut meals (cedar nut meal (CNM) and walnut meal (WNM)). The quality composition of the phenol nature was established by reactions with $10 \%$ alcohol solutions of $\mathrm{FeCl}_{3}, \mathrm{NaOH}, \mathrm{AlCl}_{3}$ and cyanidin test. The content of hydroxycinnamic acids (with recalculation for chlorogenic acid)
} 
was determined by the spectrophotometric method. The amount of tanning substances - by the method of permanganometry. The analysis of the sum of flavonoids (in recalculation for rutin) was realized by the method of differential spectrophotometry. Carbonic acids were identified by the method of gas-liquid chromatography. There were revealed quality differences in the composition of substances of the phenol nature for CNM and WNM. WNM is characterized by the higher content of hydroxycinnamic acids - in 2,5 times, tanning substances - in 3,1 times and flavonoids - in 60 times, comparing with CNM. The content of unsaturated fats in WNM is $95,79 \%$ of the total number of fats, and in CNM - 80,05\%. The ratio Omega-3/Omega- 6 for the fat component of CNM is $1 / 0,06$, and for WNM fats - 1/1,3. WNM comparing with CNM is characterized by the higher content of malic (in 5,3 times) and fumaric (in 100 times)acid. CNM contains more lemon (in 2,9 times) and succinic (in 2,2 times) acid. That is, identification of the content of some biologically active substances in nut meals allows to recommend them for usage in technologies of food products. It allows to enrich them with phenol compounds, polyunsaturated fats and organic acids.

Keywords: meal, walnut, cedar nut, biologically active substances, phenol compounds.

DOI: $10.21303 / 2504-5695.2019 .00855$

(C) Elena Shydakova-Kameniuka, Anna Novik, Yevhenii Zhukov, Yuliia Matsuk, Anna Zaparenko, Philipp Babich, Svitlana Oliinyk

\section{Introduction}

For today there is observed the stable deficit of biologically active substances in nutrition. It causes the decrease of the human organism resistance to the influence of negative ecological factors, rise of immune-deficiency states, metabolism disorders, increase of the risk of alimentarydependent diseases, their chronization and so on. That is why one of urgent directions of the modern food industry development is creation of products including biologically active compounds $[1,2]$. Biologically active substances are used to be divided in three groups: nutriceutics, minor components and probiotics [3]. Nutriceutics include essential nutrients (irreplaceable amino acids, polyunsaturated fatty acids, vitamins, some mineral substances and so on). Minor food components (organic acids, phenol compounds and so on) are not essential substances, but realize a series of physiological functions in the human organism - positively influence metabolic processes, have antioxidant, immune-stimulating, antimicrobial, adaptogenic effect and so on [4]. Probiotics are substances, normalizing the activity of the microflora of digestive organs. So, a search for new types of raw material that contain the aforesaid compounds is topical.

It may be promising to use secondary raw materials, especially ones of oil production in food technologies. Oil production volumes stably grow - especially in 2017/2018 comparing with 2016/2017 world oil and fat production grew by 2,4\% [5]. As a result the amount of secondary products - oilcakes and meals, which mass is up to $40 \%$ of the initial amount of raw materials, grows. These products are cheap biologically active raw material resource for food industry [6].

Based on realized analytic and experimental studies, it has been noted, that the essential amount of substances, healthy for humans, is contained in nut meals - cedar nut meal (CNM) and walnut meal (WNM). Supplements are characterized by the high content of biologically active proteins (38,59 and 33,63\% respectively), mineral elements (potassium, magnesium, cooper, manganese, zinc and nickel), food fibers (18,79 and 10,99\% respectively) [7, 8]. These substances must come in the human organism regularly for providing its normal functioning.

Important functions for providing the life activity of the human organism are also inherent to polyunsaturated fatty acids, organic acids and phenol compounds. It is known, that polyunsaturated fatty acids normalize the metabolism of cholesterol that prevents the development of atherosclerosis, reinforces protective functions of the organism and so on $[9,10]$. Organic acids (lemon, succinic and so on) positively influence metabolism, improve digestion processes, activates peristalsis of the intestine, inhibit the development of pathogenic microorganisms, have anti-inflammatory and antioxidant properties [11]. Phenol compounds have antioxidant, anti-microbial and immune-stimulating effects on the human organism $[12,13]$. It is also known, that substances of the phenol nature and organic acids favor the prolongation of storage terms of food products due to the presence of antioxidant and antimicrobial properties. It may be taken into account at developing food products with prolonged storage terms.

Taking it into account, the aim of the work was to identify the content of some biologically active substances (phenol compounds, fatty and organic acids) in nut meals (ones of walnut and ce- 
dar nut). It allows to determine prospects of using these nut meals for improving food and biological values of food products.

\section{Materials and Methods}

\section{1. Research materials}

The subject of the research was chosen as nut meals - CNM and WNM (Fig. 1). Meals were obtained at PE "Scientific-production firm "Elitphyto" (Ivano-frankivsk, Ukraine) by the method of cold pressing.
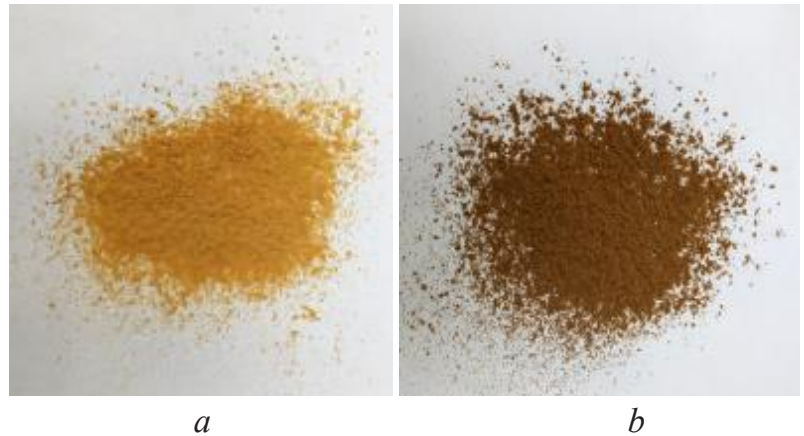

Fig. 1. Photographic image of research objects: $a-\mathrm{CNM} ; b-\mathrm{WNM}$

\section{2. Methods of studying the quality composition of phenol compounds}

For identifying the quality composition of phenol compounds, there were used extracts from nut meals. A batch of the correspondent meal with the weight near $50 \mathrm{~g}$ was poured by ethanol (1:2). Extracting was realized at periodical mixing during 2 days at temperature $20 \pm 2{ }^{\circ} \mathrm{C}$. The obtained extract was filtered under vacuum, washing the meal by $50 \mathrm{ml}$ of $50 \%$ ethanol. The obtained filtrate was steamed on the rotation-vacuum evaporator at temperature $60{ }^{\circ} \mathrm{C}$ to volume $10 \ldots 15 \mathrm{ml}$. The obtained residue was mixed with $96 \%$ ethanol (1:5), sediment was filtered, filtrate was steamed to the dry residue. The obtained residue was dissolved by $50 \%$ ethanol in a measuring flask to volume $25 \mathrm{ml}$. All further analyzes were carried out with this extract. The quality composition of phenol compounds was established by the cyanidin test, reactions with $10 \%$ alcohol solutions $\mathrm{Cl}_{3}, \mathrm{NaOH}, \mathrm{AlCl}_{3}$.

\section{3. Methods of studying the content of hydroxycinnamic acids}

The content of hydroxycinnamic acids in studied samples was determined by the spectrophotometric method (spectrophotometer SP-46 (LOMO, Russia)) by SPU method (addition 3, "Nettle leaves") [14].

Preparation of the test solution: $1 \mathrm{ml}$ of extract (p. 2.2) of the correspondent meal was placed in a measuring flask with holding capacity $10 \mathrm{ml}$, then there were successively added, mixing after each introduction: $2 \mathrm{ml}$ of $0,5 \mathrm{M}$ solution of hydrochloric acid, $2 \mathrm{ml}$ of the fresh solution of sodium nitrite and sodium molybdate ( $10 \mathrm{~g}$ of sodium nitrite and $10 \mathrm{~g}$ of sodium molybdate were preliminarily dissolved in $100 \mathrm{ml}$ of water), $2 \mathrm{ml}$ of the solution of dissolved sodium hydroxide.

Preparation of the compensatory solution: $1 \mathrm{ml}$ of the initial solution was placed in a measuring flask with holding capacity $10 \mathrm{ml}$, then there were successively added, mixing after each introduction: $2 \mathrm{ml}$ of $0,5 \mathrm{M}$ solution of hydrochloric acid, $2 \mathrm{ml}$ of the solution of dissolved sodium hydroxide, the solution volume was added with distilled water to the mark.

The optic density of the tested solution was measured at wave length $525 \mathrm{~nm}$ in a dish with layer width $10 \mathrm{~mm}$, using the compensatory solution as one of comparison.

The content of hydroxycinnamic acids (in \% recalculation for chlorogenic acid) was calculated by the formula:

$$
\mathrm{X}=\frac{\mathrm{A} \cdot 25 \cdot \mathrm{V}_{2}}{\mathrm{E}_{\mathrm{dm}}^{1 \%} \cdot \mathrm{m} \cdot \mathrm{V}_{1}}
$$


where $A$ - optic density of the tested solution at wave length $525 \mathrm{~nm}$, un.; $m$ - batch mass of the tested raw material, $\mathrm{g} ; \mathrm{E}_{\mathrm{dm}}^{1 \%}-$ specific index of absorption of chlorine acid, $\mathrm{E}_{\mathrm{dm}}^{1 \%}=188 \mathrm{un}$.; $\mathrm{V}_{1}-$ volume of the sample for analysis, $\mathrm{cm}^{3} ; \mathrm{V}_{2}$ - solution volume, $\mathrm{cm}^{3}$.

\section{4. Methods of studying the content of tanning substances}

The quantity content of the sum of tanning substances was determined by the method of permanganometry by the method SP XI [15] using the standard sample of tannin that corresponds to requirements of European pharmacopeia [16].

$2 \mathrm{~g}$ of the studied meal was placed in a conic flask of $500 \mathrm{ml}$, poured with $250 \mathrm{ml}$ of boiling water, boiled on the water bath during $30 \mathrm{~min}$ at periodical mixing. The extract was cooled to the room temperature and filtered in a conic flask with holding capacity $200 \ldots .250 \mathrm{ml} .25 \mathrm{ml}$ of the obtained extract were taken by a pipette in a conic flask with holding capacity $750 \mathrm{ml}$, added with $500 \mathrm{ml}$ of water, $25 \mathrm{ml}$ of the solution of indigo sulphonic acid and titrated at continuous shaking by the solution of potassium permanganate $(0,02 \mathrm{~mol} / \mathrm{l})$ to the gold-yellow coloration. In parallel the control experiment was realized: $25 \mathrm{ml}$ of the solution of indigo sulphonic acid and $525 \mathrm{ml}$ of water, titrated by the solution of potassium permanganate $(0,02 \mathrm{~mol} / \mathrm{l})$.

The content of tanning substances (X) (in \%) in recalculation for the absolutely dry raw material was calculated by the formula:

$$
\mathrm{X}=\frac{\left(\mathrm{V}-\mathrm{V}_{1}\right) \cdot \mathrm{K} \cdot 250 \cdot 100 \cdot 100}{\mathrm{~m} \cdot 250 \cdot(100-\mathrm{W})}
$$

where $\mathrm{V}$ - volume of the potassium permanganate solution $(0,02 \mathrm{~mol} / \mathrm{l})$, spent for titration of the experimental extract, $\mathrm{ml} ; \mathrm{V}_{1}$ - volume of the potassium permanganate solution $(0,02 \mathrm{~mol} / \mathrm{l})$, spent for titration in the control experiment, in $\mathrm{ml} ; \mathrm{m}$ - raw material mass, $\mathrm{g}$; $\mathrm{W}$ - mass losses at drying the raw material, \%; 250 - total volume of the extract, $\mathrm{ml} ; 25$ - volume of the extract, taken for titration, $\mathrm{ml}$; $\mathrm{K}$ - amount of tanning substances that corresponds to $1 \mathrm{ml}$ of the potassium permanganate solution $(0,02 \mathrm{~mol} / \mathrm{l})$ in recalculation for tannin, in $\mathrm{g}$ (for condensed tanning substances $\mathrm{K}=0,00582)$.

\section{5. Methods of studying the content of flavonoids}

The analysis of the sum of flavonoids was realized by the method of differential spectrophotometry using the reaction of complex creation of flavonoids with aluminium chloride according to method [17] (article "Tutsan grass"). SSS of rutin was used as a standard.

$1 \mathrm{~g}$ of the studied meal was placed in a flask with a microsection with holding capacity $100 \mathrm{ml}$, added with $30 \mathrm{ml}$ of $70 \%$ ethanol. The flask was weighed, fixed to the reverse refrigerator and heated for 2 hours on the water bath, periodically shaking. After cooling a mass loss was compensated by $70 \%$ ethanol up to the previous mass, kept for 1 hour, filtered (solution A).

A measuring flask with holding capacity $25 \mathrm{ml}$ was filled with $1 \mathrm{ml}$ of A solution, $1 \mathrm{ml}$ of the aluminium chloride solution in $2 \%$ ethanol and the solution volume was added by $96 \%$ ethanol to the mark. In $40 \mathrm{~min}$ the optic density of the solution was measured on the spectrophotometer SP-6 at wave length $410 \mathrm{~nm}$ in a dish with layer width $10 \mathrm{~mm}$. The solution of $1 \mathrm{ml}$ of the extract, 1 drop of dissolved acetic acid, added with $96 \%$ ethanol to the mark in the measuring flask with holding capacity $25 \mathrm{ml}$, was used as one of comparison.

Preparation of the solution of the State standard sample (SSS) of rutin: near 0,005 $\mathrm{g}$ (strict batch) of rutin SSS, preliminarily dried at temperature $130 \ldots 135{ }^{\circ} \mathrm{C}$ during 3 hours, is dissolved in $85 \mathrm{ml}$ of $95 \%$ ethanol in a measuring flask with holding capacity $100 \mathrm{ml}$ at heating on the water bath, cooled, transferred in the measuring flask with holding capacity $100 \mathrm{ml}$, the solution volume is added by ethanol to the mark.

The calculation of the content of the sum of flavonoids in recalculation for rutin and absolutely dry substance was realized by the formula:

$$
X=\frac{A_{1} \cdot a_{0} \cdot 30 \cdot 100}{A_{0} \cdot a \cdot(100-W)},
$$


where $\mathrm{A}_{1}$ - optic density of the studied solution; $\mathrm{A}_{0}$ - optic density of the solution of rutin SSS: $\mathrm{a}$ - raw material mass, $\mathrm{g}$; $\mathrm{a}_{0}$ - rutin SSS mass, $\mathrm{g}$; $\mathrm{W}$ - mass losses at drying, $\mathrm{g}$.

\section{6. Method of analyzing the content of organic and fatty acids}

The study of organic and fatty acids was realized by the method of gas-liquid chromatography. The research method is presented in detail in [18].

\section{Results of research}

\section{1. Study of the quality composition of phenol compounds}

There were realized a series of quality reactions for the presence of phenol compounds in nut meals (Fig. 2). Alcohol extracts with CNM and WNM were used for that.

There were revealed quality differences in the composition of substances of phenol nature for CNM and WNM. The presence of the intensive dark-blue coloration in the extract with WNM with $10 \%$ of alcohol solution $\mathrm{FeCl}_{3}$ testifies to the high content of tanning substances in it.

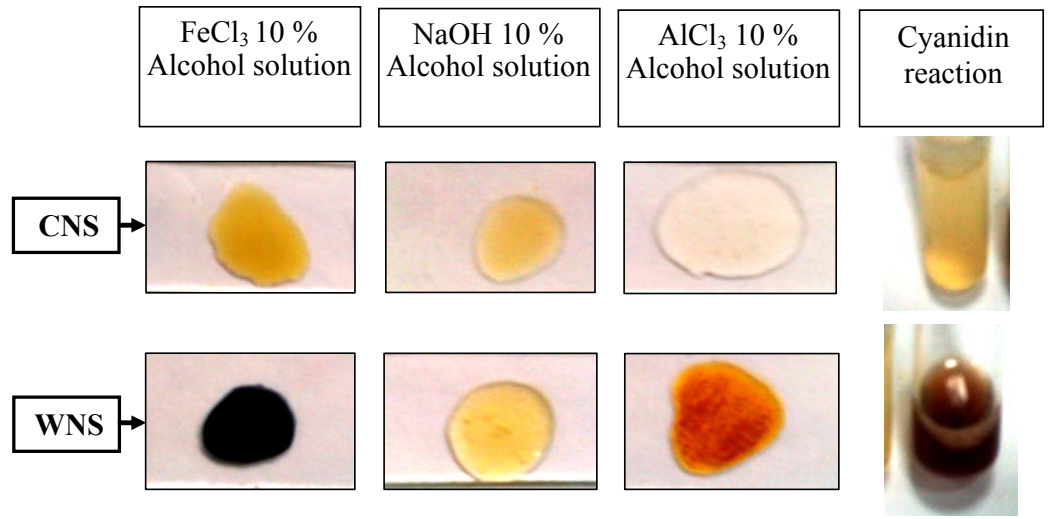

Fig. 2. Identification of the presence of phenol compounds in nut meals

This extract has also the more intensive coloration in reactions by $10 \%$ alcohol solutions of $\mathrm{NaOH}, \mathrm{AlCl}_{3}$ and by the cyanidin test. This fact means that WNM includes more hydroxycinnamic acids and flavonoids comparing with CNM.

\section{2. Study of the quantity composition of phenol compounds}

Identification of the quantity composition of phenol compounds in nut meals is presented on Fig. 3.

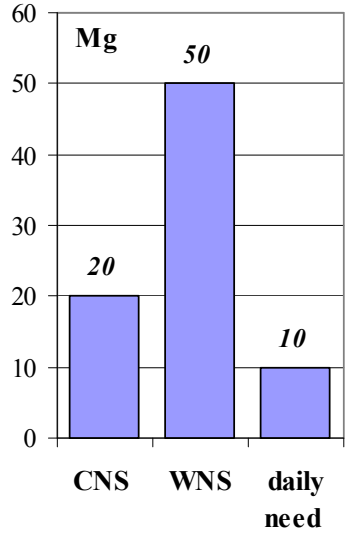

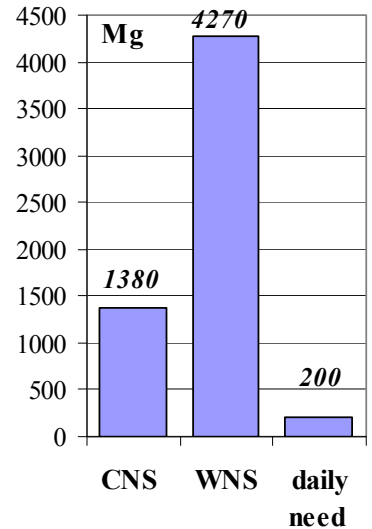

$b$

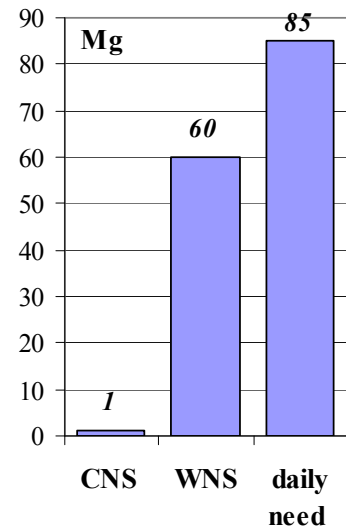

C

Fig. 3. Daily need (mg/day) and content of phenol compounds in nut meals (mg/100 g): $a$ - hydroxycinnamic acids; $b$ - tanning substances; $c$ - flavonoids 
It is noted, that WNM is characterized by the higher content of hydroxycinnamic acids - in 2,5 times, tanning substances - in 3,1 times and flavonoids - in 60 times, comparing with CNM. The daily need of the organism (established according to [19]) in hydroxycinnamic acids may be satisfied at the expanse of consuming $50 \mathrm{~g}$ of CNM or $20 \mathrm{~g}$ of WNM. The daily amount of tanning substances is contained in $15 \mathrm{~g}$ of CNM or in 4,7 $\mathrm{g}$ of WNM. The content of flavonoids in CNM is insufficient, whereas $100 \mathrm{~g}$ of WNM contain near $70 \%$ of the daily norm of these compounds. That is WNM may be recommended for using in food rations fresh or in the composition of food products for enriching them with hydroxycinnamic acids, tanning substances and flavonoids. The use of CNM allows to enrich food rations with hydroxycinnamic acids and tanning substances. It is known, that hydroxycinnamic acids are characterized with antimicrobial and immune-modeling properties; tanning substances have astringent, anti-inflammatory, bactericidal effect; flavonoids strengthen vessels, prevent the development of allergies, normalize the blood pressure and so on [4, 20-22].

\section{3. The study of the content of organic and fatty acids in nut meals}

It is noted, that nut meals include physiologically essential amount of polyunsaturated fatty acids and organic acids (oxalic, succinic, lemon, malic) (Fig. 4, 5, Table 1, 2).

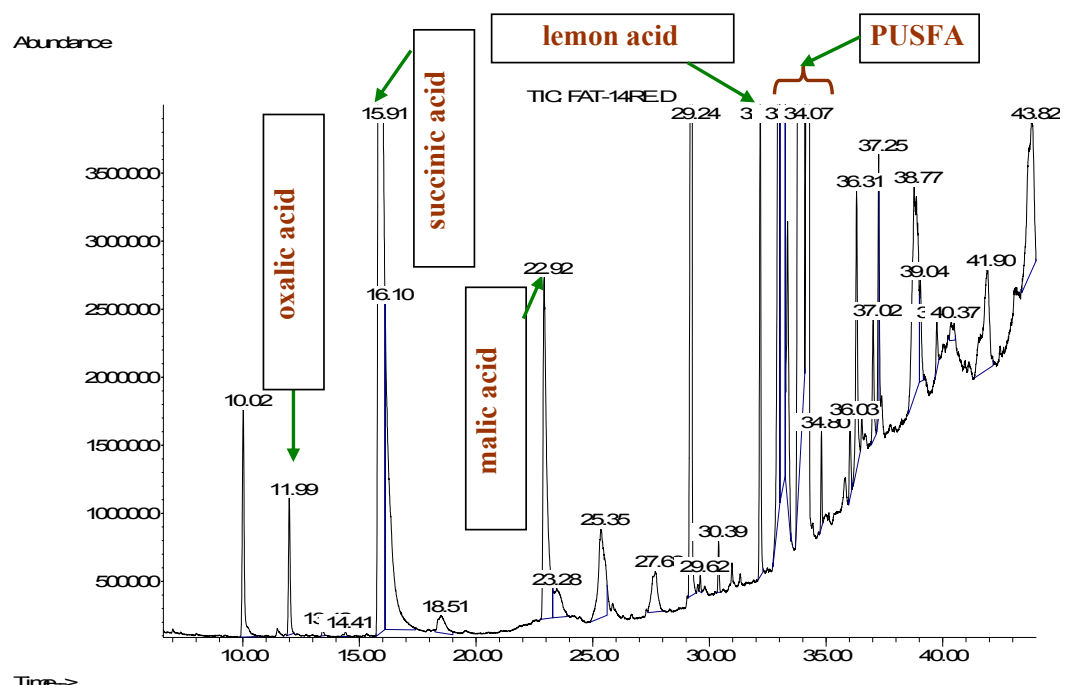

Fig. 4. Chromatographic studies of cedar nut meal

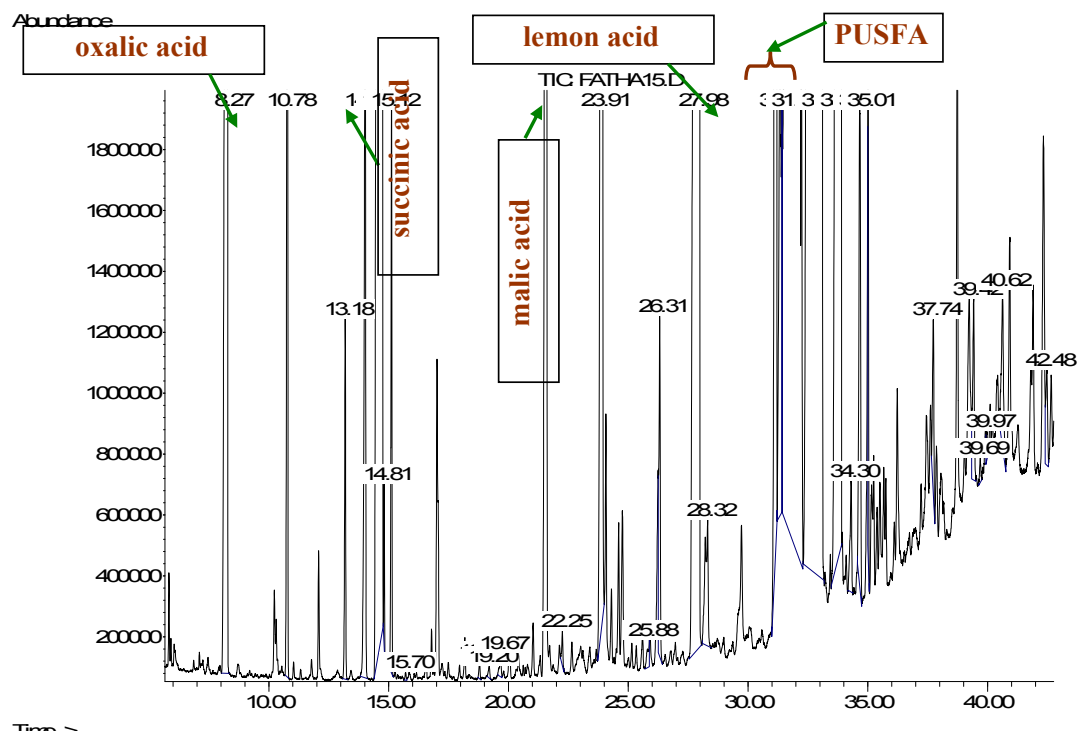

Fig. 5. Chromatographic studies of walnut meal 
It is noted, that WNM fats are characterized with the higher unsaturation degree than CNM. The content of unsaturated acids in WNM is $95,79 \%$ of the total amount of fats, and in CNM $80,05 \%$ (Table 1).

Table 1

Identification of the fatty acid composition of nut meals by the data of chromatographic study

\begin{tabular}{|c|c|c|}
\hline \multirow{2}{*}{ Fatty acids } & \multicolumn{2}{|c|}{ Content, \% of fat mass } \\
\hline & In CNM & In WNM \\
\hline Saturated, including: & 19,95 & 4,21 \\
\hline lauric $\mathrm{C}_{12: 0}$ & - & 0,04 \\
\hline Myristic $\mathrm{C}_{14: 0}$ & 0,77 & 0,06 \\
\hline Pentadecanoic $\mathrm{C}_{15: 0}$ & 1,95 & - \\
\hline palmitic $\mathrm{C}_{16: 0}$ & 8,56 & 0,49 \\
\hline margarine $\mathrm{C}_{17: 0}$ & 0,18 & - \\
\hline stearic $\mathrm{C}_{18: 0}$ & 4,78 & 1,79 \\
\hline Arachic $\mathrm{C}_{20: 0}$ & 0,35 & 1,11 \\
\hline behenic $\mathrm{C}_{22: 0}$ & 0,77 & 0,29 \\
\hline tricosanic $\mathrm{C}_{23: 0}$ & 0,30 & - \\
\hline lingoceric $\mathrm{C}_{24: 0}$ & 2,30 & 0,43 \\
\hline Monounsaturated, including: & 26,98 & 40,97 \\
\hline palmitoleic (Omega-7) $\mathrm{C}_{16: \ln 9}$ & 0,06 & 20,68 \\
\hline oleic (Omega-9) $\mathrm{C}_{18: \ln 9}$ & 26,92 & 20,29 \\
\hline Polyunsaturated, including: & 53,07 & 54,82 \\
\hline linoleic (Omega-6) $\mathrm{C}_{18: 2 \mathrm{n} 9,12}$ & 2,89 & 31,41 \\
\hline linolenic (Omega-3) $\mathrm{C}_{18: 3 \mathrm{n} 9,12,15}$ & 50,18 & 23,41 \\
\hline
\end{tabular}

These supplements have familiar contents of polyunsaturated fatty acids, but linolenic acid prevails in the composition of CNM, and linoleic one - in WNM. Omega-3/Omega-6 ratio for the fatty component of CNM is $1 / 0,06$, and for fats of $\mathrm{CNM}-1 / 1,3$. The optimal ratio of Omega-3/ Omega- 6 in nutrition must be $1 / 4[23,24]$. That is why nut meals may be recommended for using in technologies of food products, containing polyunsaturated fatty acids Omega-6, for example, if sunflower oil is a recipe component.

Some multi-base carbonic acids are also related to biologically active substances (Table 2).

Table 2

Identification of other biologically active substances in nut meals by the data of chromatographic study

\begin{tabular}{ccc}
\hline \multirow{2}{*}{ Multi-base carbonic acids } & \multicolumn{3}{c}{ Content, \% of fat mass } \\
\cline { 2 - 3 } & In CNM & In WNM \\
\hline Lemon & $\mathbf{8 , 1 0}$ & 2,80 \\
Malic & 7,30 & $\mathbf{3 9 , 0 0}$ \\
Fumaric & 0,07 & $\mathbf{7 , 0 0}$ \\
Sicconic & $\mathbf{8 , 0 0}$ & 3,60
\end{tabular}

Comparing with CNM, WNM is characterized by the higher content of malic acid (in 5,3 times) and fumaric (in 100 times). CNM contains more lemon acid (in 2,9 times) and sicconic (in 2,2 times). Taking into account the fact that the recommended consumption norm of organic acids is near $500 \mathrm{mg} /$ day [19], CNM and WNM cannot be considered as a source of these substances. But their use in food products allows to increase the content of these nutrients a little.

\section{Conclusions}

The identification of the content of some biologically active substances in nut meals (walnut meals and cedar meals) was realized. It has been established that WNM is characterized by the 
higher content of hydroxycinnamic acids - in 2,5 times, tanning substances - in 3,1 times and flavonoids - in 60 times, comparing with CNM.

It is noted, that WNM fats are characterized with the higher unsaturation degree than CNM. Omega-3/Omega-6 ratio for the fatty component of CNM is $1 / 0,06$, and for fats of CNM - 1/1,3. That is why nut meals may be recommended for using in technologies of food products, containing polyunsaturated fatty acids Omega-6, It allows to approximate Omega-3/ Omega-6 ratio to the optimal one (1/4).

WNM is characterized by the higher content of malic acid (in 5,3 times) and fumaric (in 100 times), CNM - lemon acid (in 2,9 times) and sicconic (in 2,2 times).

The research results allow to make a conclusion about the expedience of introducing CNM and WNM in the composition of food products for enriching them with phenol compounds, polyunsaturated fats and organic acids. But the presented studies don't take into account a possible influence of technological factors on the stability of the studied biologically active substances that is a weak side of the presented materials. At preparing food products these compounds can usually interact with other recipe components and undergo the influence of high temperatures, $\mathrm{pH}$ medium and so on. For developing the obtained results, the authors plan to study possibilities of using nut meals for improving food and biological values of especially rich cookies, identifying the content of biologically active substances in a ready product.

\section{References}

[1] Belousova, O. V., Belousov, Ye. A., Ivaschenkova, A. O. (2016). Biologically active supplements as a perspective direction of development of the pharmaceutical market. Nauchnyiy rezultat, 4 (4), 89-94.

[2] Vidigal, M. C. T. R., Minim, V. P. R., Simiqueli, A. A., Souza, P. H. P., Balbino, D. F., Minim, L. A. (2015). Food technology neophobia and consumer attitudes toward foods produced by new and conventional technologies: A case study in Brazil. LWT - Food Science and Technology, 60 (2), 832-840. doi: https://doi.org/10.1016/j.lwt.2014.10.058

[3] Poznyakovskiy, V. M. (2012). Urgent problems of modern nutriciology: terms and definitions, classification of food raw materials and food products. Tekhnika i tekhnologiya pishchevyh proizvodstv, 3, 1-8.

[4] Ghasemzadeh, A., Ghasemzadeh, N. (2011). Flavonoids and phenolic acids: Role and biochemical activity in plants and human. Journal of Medicinal Plants Research, 5 (31), 6697-6703. doi: https://doi.org/ 10.5897/jmpr11.1404

[5] Prodovolstvennyiy prognoz. Kratkiy obzor ryinkov. (2018). Available at: http://www.fao.org/3/ CA0910RU/ca0910ru.pdf

[6] Milner, J. A. (1999). Functional Foods and Health Promotion. The Journal of Nutrition, 129 (7), 1395S-1397S. doi: https://doi.org/10.1093/jn/129.7.1395s

[7] Shidakova-Kamenyuka, E., Novik, A., Kasabova, K., Kravchenko, O. (2015). The perspectives of using extraction cake of nuts for the enrichment of floury confectionary products. Prohresyvni tekhnika ta tekhnolohiyi kharchovykh vyrobnytstv restorannoho hospodarstva i torhivli, 2 (13), 69-81.

[8] Shydakova-Kamenyuka, E., Novyk, A., Bolxovytyna, E. (2017). Analyz soderzhanyya osnovnyx pyshhevyx veshhestv v produktax pererabotky greczkogo y kedrovogo orexa. Scientifis Letters of Academic of Michal Baludansky, 5 (4), 121-124.

[9] Patel, M. R., San Martin-Gonzalez, M. F. (2012). Characterization of Ergocalciferol Loaded Solid Lipid Nanoparticles. Journal of Food Science, 77 (1), N8-N13. doi: https://doi.org/10.1111/j.17503841.2011.02517.x

[10] Popov, E. S., Rodyonova, N. S., Sokolova, O. A., Mazurenko, N. Yu. (2016). Estimation of prospects of the production from domestic vegetable raw materials balanced on polyunsaturated fatty acids. Hygiene \& Sanitation (Russian Journal), 95 (1), 79-83.

[11] Tolstikova, T. G., Tolstikov, A. G., Tolstikov, G. A. (2010). Lekarstva iz rastitel'nyh veshchestv. Novosibirsk: Geo, 215.

[12] Rockenbach, I. I., Rodrigues, E., Gonzaga, L. V., Caliari, V., Genovese, M. I., Gonçalves, A. E. de S. S., Fett, R. (2011). Phenolic compounds content and antioxidant activity in pomace from 
selected red grapes (Vitis vinifera L. and Vitis labrusca L.) widely produced in Brazil. Food Chemistry, 127 (1), 174-179. doi: https://doi.org/10.1016/j.foodchem.2010.12.137

[13] Kroon, P. A., Clifford, M. N., Crozier, A., Day, A. J., Donovan, J. L., Manach, C., Williamson, G. (2004). How should we assess the effects of exposure to dietary polyphenols in vitro? The American Journal of Clinical Nutrition, 80 (1), 15-21. doi: https://doi.org/10.1093/ajcn/80.1.15

[14] Derzhavna Farmakopeya Ukrayini. Derzhavne pidpriemstvo «Ukrayinskiy naukoviy farmakopeyniy tsentr yakosti likarskih zasobiv» (2018). Kharkiv, 416.

[15] Gosudarstvennaya farmakopeya SSSR. Obschie metody analiza (1987). Moscow, 11 (1), 194.

[16] European Pharmacopoeia (2004). Strasbourg, 2570.

[17] Derzhavna Farmakopeya Ukrayini. Derzhavne pidpriemstvo «Ukrayinskiy naukoviy farmakopeyniy tsentr yakosti likarskih zasobiv» (2018). Kharkiv, 336.

[18] Bubenchikova, V. N., Starchak, Yu. A. (2014). The amino acid, fatty acid and polysaccharides composi-tion of the Thymus pallasianus L. Herb. Chemistry of plant raw material, 3, 191-194. doi: https://doi.org/10.14258/jcprm.1403191

[19] Rekomenduemye yrovni potrebleniya pyshchevyh i byologicheski aktivnyh veshestv (2004). Moscow, 46.

[20] Majewska, M., Skrzycki, M., Podsiad, M., Czeczot, H. (2011). Evaluation of antioxidant potential of flavonoids: an in vitro study. Acta Poloniae Pharmaceutica, 68 (4), 611-615.

[21] Adwan, G., Abu-Shanab, B., Adwan, K. (2010). Antibacterial activities of some plant extracts alone and in combination with different antimicrobials against multidrug-resistant Pseudomonas aeruginosa strains. Asian Pacific Journal of Tropical Medicine, 3 (4), 266-269. doi: https://doi.org/10.1016/s19957645(10)60064-8

[22] Gong, Y., Pegg, R. B. (2015). Tree nut oils. Specialty Oils and Fats in Food and Nutrition, 65-86. doi: https://doi.org/10.1016/b978-1-78242-376-8.00003-x

[23] Gómez Candela, C., Bermejo López, L. M., Loria Kohen, V. (2011). Importance of a balanced omega 6/omega 3 ratio for the maintenance of health. Nutritional recommendations. Nutrición Hospitalaria, 26 (2), 323-329.

[24] Kang, J. X., Wan, J.-B., He, C. (2014). Concise Review: Regulation of Stem Cell Proliferation and Differentiation by Essential Fatty Acids and Their Metabolites. STEM CELLS, 32 (5), 1092-1098. doi: https://doi.org/10.1002/stem.1620 